[4] Yevlash, V. V., Niemirich, O. V., Malafaiev, M. T. (2012). Strukturno-mekhanichni kharakterystyky mlyntsevoho tista z poroshkom z kapusty. Khlebolekarskoe y kondyterskoe delo, 4 (43), 20-22.

[5] Belitz, H.-D. Grosch, W., Schieberle, P. (2009). Food Chemistry. Springer, 1070. doi: https:// doi.org/10.1007/978-3-540-69934-7

[6] Cui, S. (Ed.) (2005). Food Carbohydrates: Chemistry, Physical Properties and Applications. CRC Press, 432. doi: ttps://doi.org/10.1201/9780203485286

[7] Shujun, W. Jinglin, Yu., Wenyuan, G. (2005). Use of x-ray diffractometry (XRD) for identification of Fritillaria according to geographical origin. American Journal of Biochemistry and Biotechnology, 1 (4), 199-203. doi: https://doi.org/10.3844/ajbbsp.2005.199.203

[8] Lugovskoy, A. A., Poplavskii, Y. A., Serdyukov, V. I., \& Sinitsa, L. N. (2011). Experimental setup for spectrophotometric study of water clusters in nanoporous material. Atmospheric and Oceanic Optics, 24(5), 502-507. doi: https://doi.org/10.1134/s1024856011050125

[9] Ozaki, Y., McClure, W. F., Christy, A. A. (Eds.) (2006). Near-Infrared Spectroscopy in Food Science and Technology. Wiley-Interscience, 408. doi: https://doi.org/10.1002/0470047704

[10] Karge, H. G., Weitkamp, J. (Eds.) (2008). Adsorption and Diffusion, Springer Science \& Business Media, Berlin, 400. doi: https://doi.org/10.1007/978-3-540-73966-1

\title{
DEVELOPMENT OF THE NEW POINT SCALE OF ORGANOLEPTIC EVALUATION AT MANUFACTURING ORGANIC CAKES
}

\author{
Alina Tkachenko \\ Department of commodity of foodstuff \\ Higher Educational Establishment of Ukoopspilka «Poltava University of Economics and Trade» \\ 3 Koval str., Poltava, Ukraine, 36014 \\ alina_biaf@ukr.net
}

\begin{abstract}
The article presents the ground of developing the 50-point scale for evaluating cakes by organoleptic parameters. The aim of the article is to create the new point scale of organoleptic evaluation for using at producing organic cakes. It was established, that for today such important parameters as "flavor", "post-flavor", "porosity structure" are not always used at the organoleptic evaluation of cakes' quality. The article describes the recipes of four developed cakes, produced of the organic raw materials - "Grechanyk", based on buckwheat flour, "Zhytnytsa', based on rye flour, "Golden amaranth", based on amaranth flour and "Hempen delight", based on hempen flour. For evaluating organoleptic characteristics of cakes, there was presented 50-point scale that includes evaluation of the following parameters: form, surface condition, color of crust, condition and color of crumble, porosity structure, smell, taste, flavor, post-taste, malaxation of crumble. Based on the method of expert evaluations, there were determined significance coefficients for each parameter. Thus, coefficient 0,5 was set for the parameters "porosity structure" and 1,5 for "color" and "smell", the significance coefficient was equal 1 for a series of other parameters. The developed scale provided the following criteria of cakes evaluation: 45-50 points - "perfectly", 40-44 points - "well", 30-39 points - "satisfactorily", lower 30 points - "unsatisfactorily". Based on the developed scale, the developed cakes were evaluated by the gustatory commission. All developed cakes corresponded to the mark "perfectly" by organoleptic parameters. The highest index of the quality level was inherent to the cake "Grechanyk" " $-0,99$ at general sum of points for the gustatory evaluation 49,95 . The cake Zhytnytsa corresponded to 0,98 by the quality level, "Hempen delight" $-0,96$. The lowest quality level was detected in the cake "Golden amaranth" $(0,94)$, that is caused by the specific taste of amaranth flour.
\end{abstract}

Keywords: point scale, significance coefficient, organoleptic parameters, organic cakes, quality level.

DOI: 10.21303/2504-5695.2018.00666

(C) Alina Tkachenko

\section{Introduction}

Sensor or organoleptic methods, based on the analysis of feelings of human sense organs, are widely used for evaluating consumption advantages of food products [1] Earlier there were offered the methods of mathematical statistics, numerical modeling and forecasting that give a 
possibility to transfer the organoleptic evaluation of products' quality to the quantitative category from the qualitative one that allows to approach it to results of other analytic methods by exactness and results reproducibility [2].

The main organoleptic characteristics of cakes are form, surface, color, outlook in fracture, taste and smell. The point scale is used for their evaluation taking into account indices of significance parameters [3]. There is offered the profile evaluation of organoleptic parameters of cakes, including separation of such parameters as outlook, outlook in fracture, color, smell, taste in simple components - descriptors, which intensity was evaluated by tasters by the 5-point scale of intensity, namely: 0 - a sign is absent; 1 - hardly felt; 2 - weak intensity; 3 -moderate intensity; 4 - strong intensity; 5 - very strong intensity [4]. Work [5] offers to use the 50-point scale using such parameters as "flavor", "consistence" and "expressiveness of a supplement". There are also offered the other parameters - smell, taste, post-taste, texture [6]. This evaluation scale provides participation of 50 respondents at evaluating organoleptic parameters of products. Marks from 1 to 9 were put for each parameter, and in works $[7,8]$ the parameter "post-taste" is not included. The analogous approach is used in works $[9,10]$, based on the method of questioning consumers by the 9-point scale of evaluation of organoleptic characteristics of cakes. But in such cases consumers evaluated a general impression from a product. In one case [9] there are described results of questioning consumers in a super-market, in another one [10] - results of questioning students and workers of a university. The scale provides the use of marks from 1 (extremely unpleasant) to 9 (extremely pleasant).

The aim of this study is to develop the point scale for evaluating organoleptic parameters of organic cakes. It allows to assess organoleptic quality parameters more exactly at developing new products.

\section{Materials and Methods}

Cakes, based on organic raw materials - "Grechanyk", based on buckwheat flour, "Zhytnytsa', based on rye flour, "Golden amaranth", based on amaranth flour and "Hempen delight", based on hempen flour were developed as a result of the study. The photos of samples are presented on Fig. 1.

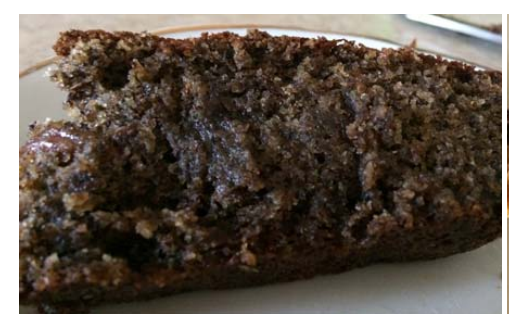

$a$

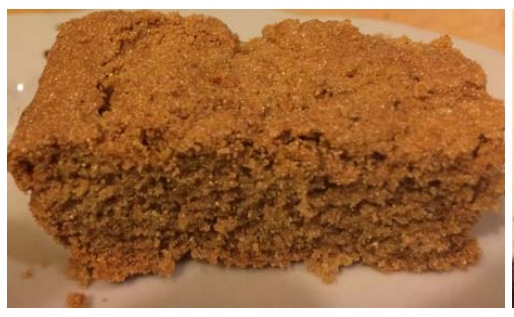

$c$

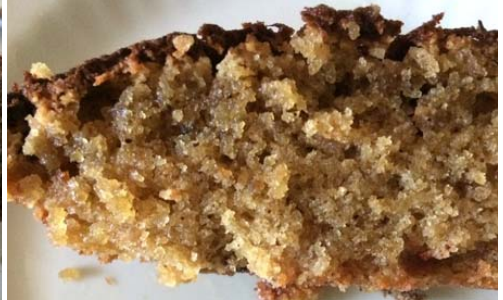

$b$

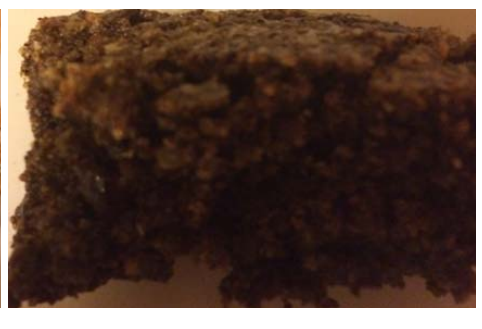

$d$

Fig. 1. Photo images of the developed cakes: $a$ - Greachanyk; $b$ - Zhytnytsa; $c-$ "Golden amaranth"; $d-$ "Hempen delight"

The recipes of the developed samples are presented in Table $\mathbf{1 .}$

The great share of raw materials, selected for producing cakes were of the Ukrainian origin. Thus, a producer of wheat, buckwheat and rye flour is PE "Agroecology" (Ukraine, Poltava region, Shyshatsky district, v. Mykhailyky). A producer of amaranth flour is IE "Mirgorod N. V." 
(Ukraine, c. Cherkasy), hempen flour - "Ekosvit" (Ukraine, c. Sumy). For producing cakes, there was taken organic cane sugar, produced by TM "Sladov" (Ukraine, c. Kyiv), creamy butter 82,6 \% Organic Milk (Ukraine, Zhitomir region, v. Baranovka). Pumpkin syrup for producing cakes was made independently of organic raw materials, and agave and rice syrups were made by "Organic Light" (USA). Dry fruits were made by "Bio Planet" (Moldova), and bran and vegetable oils - also by "Bio Planet", but the country-producer is Poland.

Table 1

Consolidated recipes of developed organic cakes for $1000 \mathrm{~kg}$ of ready products

\begin{tabular}{|c|c|c|c|c|}
\hline Raw material* & "Grechanyk" & "Zhytnytsa" & "Golden amaranth" & "Hempen delight" \\
\hline Buckwheat flour & 302,86 & - & - & - \\
\hline Wheat flour & - & 202,86 & - & - \\
\hline Rye flour & - & 100,00 & - & - \\
\hline Amaranth flour & - & - & 301,00 & - \\
\hline Hempen flour & - & - & - & 303,86 \\
\hline Organic cane sugar & 200,00 & 200,00 & 200,00 & 200,00 \\
\hline Agave syrup & 27,12 & - & - & - \\
\hline Rice syrup & - & 27,12 & - & - \\
\hline Pumpkin syrup & - & - & - & 27,12 \\
\hline Creamy butter & 201,15 & 201,15 & 201,15 & 201,15 \\
\hline sesame oil & 26,00 & - & - & 26,00 \\
\hline Til oil & - & 26,00 & - & - \\
\hline Amaranth oil & - & - & 26,00 & - \\
\hline Dried winter cherry & 54,00 & - & - & - \\
\hline Dried raisins & 173,00 & - & - & - \\
\hline Dried cranberry & - & 114,00 & - & - \\
\hline Dried mulberry & - & 113,00 & - & - \\
\hline Walnuts & - & - & 110,00 & - \\
\hline Pieces of pumpkin & - & - & - & 110,00 \\
\hline Organic eggs & 27,00 & 27,00 & 27,00 & 27,00 \\
\hline Flax bran & 10,59 & - & - & - \\
\hline Rye bran & - & 10,59 & - & - \\
\hline Powder for baking & 0,9 & 0,9 & 0,9 & 0,9 \\
\hline Kitchen salt & 0,9 & 0,9 & 0,9 & 0,9 \\
\hline
\end{tabular}

Note: * only organic certified raw materials were used for producing cakes

The following parameters were taken for developing the point scale of evaluation of organoleptic parameters: form $\left(\mathrm{P}_{1}\right)$, surface condition $\left(\mathrm{P}_{2}\right)$, color of crust $\left(\mathrm{P}_{3}\right)$, condition and color of crumble $\left(\mathrm{P}_{4}\right)$, porosity structure $\left(\mathrm{P}_{5}\right)$, smell $\left(\mathrm{P}_{6}\right)$, taste $\left(\mathrm{P}_{7}\right)$, flavor $\left(\mathrm{P}_{8}\right)$, post-taste $\left(\mathrm{P}_{9}\right)$, malaxation of crumble $\left(\mathrm{P}_{10}\right)$ by the 50-point scale. According to the data of theoretical studies, the 50-point scale is used most often for evaluating organoleptic parameters of confectionary, because approximately 10 parameters are assessed, and the most optimal system of evaluation is the 5-point one. But signif- 
icance coefficients are often used. For determining significance coefficients, the method of expert evaluations was used. Each parameter was assessed by points 1,5 - very significant, 1 - significant, 0,5 - insignificant, 0 - not worth including in the scale. Parameters were evaluated by 7 experts, the value of coefficient was calculated by the formula:

$$
\mathrm{K}_{\mathrm{i}}=\sum \mathrm{P}_{\mathrm{iy}} / \mathrm{y}
$$

where $\mathrm{K}_{\mathrm{i}}$ - coefficient of significance; $\mathrm{P}_{\mathrm{iy}}$-evaluation of $\mathrm{i}$-th parameter by $\mathrm{y}$-expert; $\mathrm{y}$ - number of experts.

The results of evaluation of significance coefficients of organoleptic parameters of organic cakes are presented in Table 2.

Table 2

The results of evaluation of significance coefficients of organoleptic parameters of organic cakes

\begin{tabular}{|c|c|c|c|c|c|c|c|c|c|c|}
\hline \multirow{2}{*}{ No. expert } & \multicolumn{10}{|c|}{ Organoleptic quality parameters } \\
\hline & $\mathbf{P}_{1}$ & $\mathbf{P}_{2}$ & $\mathbf{P}_{3}$ & $\mathbf{P}_{4}$ & $\mathbf{P}_{5}$ & $\mathbf{P}_{6}$ & $\mathbf{P}_{7}$ & $\mathbf{P}_{8}$ & $\mathbf{P}_{9}$ & $\mathbf{P}_{10}$ \\
\hline 1-th & 1,5 & 1 & 0,5 & 0,5 & 0,5 & 1,5 & 1,5 & 1,5 & 1,5 & 1,5 \\
\hline 2 -th & 1 & 1 & 1 & 1 & 1 & 1,5 & 1,5 & 1 & 1 & 1 \\
\hline 3 -th & 1 & 1 & 1 & 0,5 & 1 & 1,5 & 1,5 & 1 & 1 & 1 \\
\hline 4-th & 1 & 1 & 1 & 0,5 & 0,5 & 1,5 & 1,5 & 1 & 1 & 1 \\
\hline 5 -th & 1 & 1 & 1 & 0,5 & 0 & 1 & 1 & 1 & 1 & 0,5 \\
\hline 6 -th & 1 & 1 & 1 & 0 & 0 & 1,5 & 1,5 & 1 & 0,5 & 1 \\
\hline 7-th & 1 & 1 & 1 & 0,5 & 0,5 & 1,5 & 1,5 & 1 & 1 & 1 \\
\hline Sum of points & 7,5 & 7 & 6,5 & 3,5 & 3,5 & 10 & 10 & 7,5 & 7 & 7 \\
\hline $\begin{array}{l}\text { Coefficient of } \\
\text { significance }\end{array}$ & 1,0 & 1 & 0,98 & 0,5 & 0,5 & 1,4 & 1,4 & 1,07 & 1 & 1 \\
\hline
\end{tabular}

Based on evaluating significance coefficients of organoleptic parameters, there was developed the 10-point scale of organoleptic evaluation of cakes, presented in Table 3.

Table 3

The developed 50-point scale of evaluation of organoleptic parameters of organic cakes

\begin{tabular}{ccc}
\hline Parameter & Coefficient of significance & $\begin{array}{c}\text { Maximal sum of points taking into account } \\
\text { the coefficient of significance }\end{array}$ \\
\hline Form & 1 & 5 \\
Surface condition & 1 & 5 \\
Crust color & 1 & 5 \\
Crumble condition and color & 0,5 & $5 / 2,5$ \\
Porosity structure & 0,5 & $5 / 2,5$ \\
Smell & 1,5 & $5 / 7,5$ \\
Taste & 1,5 & $5 / 7,5$ \\
flavor & 1 & 5 \\
Post-taste & 1 & 5 \\
Crumble malaxation & 1 & 5 \\
totally & - & 50
\end{tabular}


For evaluating the quality of organic cakes by organoleptic parameters, there was developed the scale, presented in Table 4.

Table 4

The scale for evaluating the quality of organic cakes by organoleptic parameters

\begin{tabular}{cc}
\hline Number of points & Evaluation of quality by organoleptic parameters \\
\hline $45-50$ & «perfectly» \\
$40-44$ & «well» \\
$30-39$ & «satisfactorily» \\
less 30 & «unsatisfactorily»
\end{tabular}

Thus, the developed scale gives a possibility to improve approaches to evaluating the quality of cakes by organoleptic parameters. It's remarkable, that the offered scale includes such parameters as "flavor" and "post-taste". The parameters "taste" and "smell" have the highest significance parameters as a result of the expert evaluation.

\section{1. Experimental procedures}

The evaluation of organoleptic parameters was carried out by the gustatory commission of experts of commodity research of food goods. The results of it are presented in Table 5.

Table 5

The results of evaluating organoleptic parameters of organic cakes

\begin{tabular}{|c|c|c|c|c|c|}
\hline Parameter & $\begin{array}{l}\text { Coefficient of } \\
\text { significance }\end{array}$ & «Grechanyk" & «Zhytnytsa" & $\begin{array}{l}\text { «Golden } \\
\text { amaranth» }\end{array}$ & $\begin{array}{c}\text { «Hempen } \\
\text { delight» }\end{array}$ \\
\hline Form & 1 & 5 & 5 & 4 & 5 \\
\hline Surface condition & 1 & 5 & 5 & 4,8 & 4,5 \\
\hline Crust color & 1 & 5 & 5 & 5 & 4,6 \\
\hline Crumble color and condition & 0,5 & $5 / 2,5$ & $4,9 / 2,45$ & $4,9 / 2,45$ & $4,9 / 2,45$ \\
\hline Porosity structure & 0,5 & $4,9 / 2,45$ & $5 / 2,5$ & $4,6 / 2,3$ & $4,9 / 2,45$ \\
\hline Smell & 1,5 & $5 / 7,5$ & $4,9 / 7,35$ & $5 / 7,5$ & $4,9 / 7,35$ \\
\hline Taste & 1,5 & $5 / 7,5$ & $4,8 / 7,2$ & $4,5 / 6,75$ & $4,9 / 7,35$ \\
\hline Flavor & 1 & 5 & 4,8 & 4,5 & 4,8 \\
\hline Post-taste & 1 & 5 & 4,8 & 4,6 & 4,6 \\
\hline Crumble malaxation & 1 & 5 & 5 & 5 & 5 \\
\hline $\begin{array}{l}\text { Total sum of points taking } \\
\text { into account the significance } \\
\text { coefficient }\end{array}$ & - & 49,95 & 49,1 & 46,9 & 48,1 \\
\hline Quality level & - & 0,99 & 0,98 & 0,94 & 0,96 \\
\hline
\end{tabular}

Thus, the developed organic cakes were highly evaluated by tasters. Based on the developed point scale, all cakes were evaluated as "perfectly". The petal diagram was constructed for better visualizing the evaluation of the quality parameters by organoleptic ones (Fig. 2).

As it can be seen on Fig. 2, all samples have practically maximal marks by organoleptic parameters, but the cake "Golden amaranth" has the lower point for the parameter "form", and "Hempen delight" - for the surface condition. 


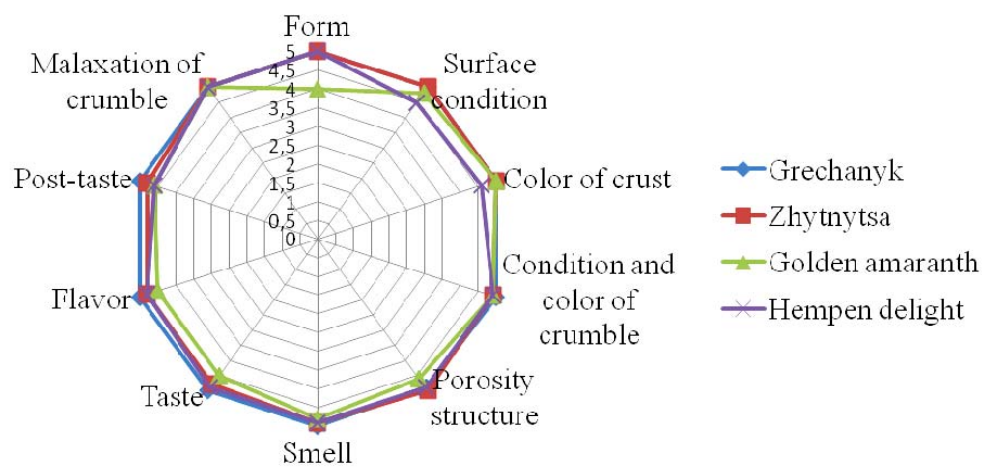

Fig. 2. Petal diagram of organoleptic quality parameters of organic cakes

\section{Results}

All samples received the maximal point for the parameter "crumble malaxation" that is explained by the good dough consistence. The parameter "form" was assessed as perfect in three samples, but the cake "Golden amaranth" received the lower number of points -4 , because amaranth flour, used at baking the cake, negatively influenced its homogeneity that is connected with the amount of gluten in flour. The parameter "crust color" received the least number of points in the cake "Hempen delight", because hempen flour gives a grayish color to ready products. The worse porosity structure was inherent to the cake "Golden amaranth" that is also connected with the amount of gluten. All samples received high marks for the parameter "smell" that is connected with used oils. The best taste was inherent to the cake "Grechanyk", on the second place - "Hempen delight", and the least number of points was received by the "Golden amaranth" that is conditioned by the specificity of amaranth flour that gave a specific tinge. The same factor influenced the mark for the "flavor"- 4,5 points, and the maximal point for it was received by the cake "Grechanyk".

The diagram of the quality level by organleptic parameters was constructed based on the results of the gustatory evaluation (Fig. 3).

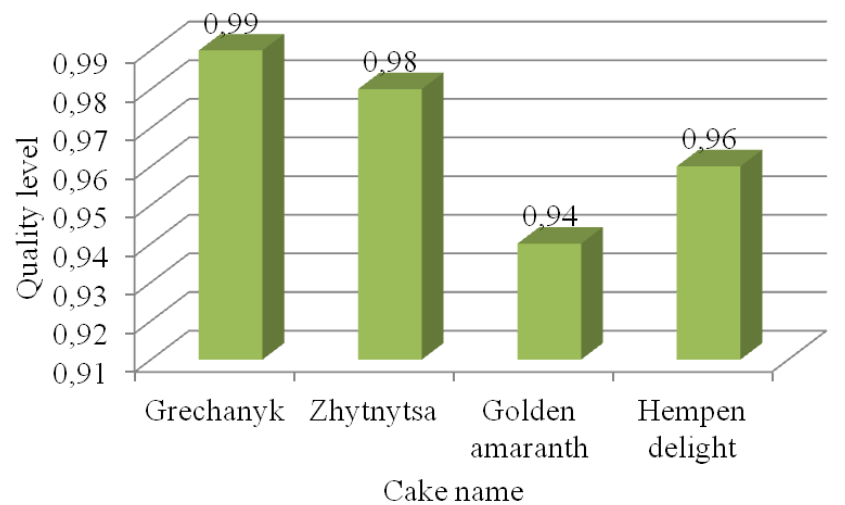

Fig. 3. Quality levels by organoleptic parameters of the developed organic cakes

The data of Fig. 3 testify that the highest quality level by organoleptic parameters was inherent to the cake "Grechanyk"- 0,99, the second place - "Zhytnitsa" $(0,98)$. The lowest quality level belongs to the cake "Golden amaranth" (0,94 points).

\section{Conclusions}

Thus, based on the research results, there was offered to use the 50-point scale of the quality evaluation of organic cakes by organoleptic parameters. This scale can be used for any cakes, not only for ones, based on organic raw materials. For evaluating cakes at the stage of their development, there was offered to evaluate the following parameters: form, surface condition, color of crust, condition and color of crumble, porosity structure, smell, taste, flavor, post-taste, malaxation 
of crumble. Based on the method of expert evaluations, it was established that the least significance coefficients must be used for the parameters "porosity structure" and "crumble condition and color", the highest ones - for "taste" and "smell". Based on the developed scale, there were evaluated 4 organic cakes "Grechanyk", "Zhytnytsa", "Golden amaranth", "Hempen delight". The highest quality level index was inherent to the cake "Grechanyk"- 0.99 at the total sum of points for the gustatory evaluation 49.95 .

The main advantage of the study is the fact that the maximum of factors that influence the quality of a product by organoleptic parameters were taken into account at developing the point scale. At the same time significance coefficients were selected using expert marks that indicate their objectivity. But for more distinct evaluation of the quality of cakes, it is necessary to take into account not only organoleptic, but also physical-chemical parameters and also ones of safety and food value. That is why the following stage of the study will be creation of the qualimetric system of evaluating cakes for the complex study of the quality parameter of products.

\section{References}

[1] Rosdina, T. (2015). Sensorniy analiz kak sostavlyayushchaya chast' tovarnoy ekspertizy pishchevykh produktov. Mezhdunarodnaya torgovlya i torgovaya politika, 4 (4), 84-86.

[2] Lilishenceva, A., Cyernigina, E. (2014). Sensorniy analiz pishchevykh produktov v ekspertize kachestva prodovol'stvennykh tovarov. Ekonomicheskiy Rost Respubliki Belarus': Globalizatsiya, Innovatsionnost', Ustoychivost'. Materialy VY Mezhdunarodnoy nauchno-prakticheskoy konferentsii, 236-237.

[3] Oleksienko, N., Nedelina, L. (2013). Sensorna otsinka yakosti kondyterskykh vyrobiv u protsesi zberihannya. APK, 5, 22-24.

[4] Donchevska, R., Pustovgar, A. (2015). Sensornyy analiz keksiv providnykh vitchyznyanykh vyrobnykiv. Mezhdunarodnyy nauchnyy zhurnal, 9, 53-58.

[5] Lozova, T. M., Kovalchuk, K. (2013). Tovaroznavchi doslidzhennya zberihannya novykh keksiv. Visnyk Lvivskoyi komertsiynoyi akademiyi. Seriya tovaroznavcha, 13, 11-13.

[6] Adubofuor J., Amoafo Mensah M. (2012). Sensory Evaluation and Proximate Composition of Rock Buns and Cakes Prepared from Partially-dried Ripe Pawpaw Pulp Incorporated into Wheat Flour. J. Agric. Food. Tech., 2 (11), 172-177.

[7] Almeida, N. T., Schmidt, H., Oliveira, V. R. D. (2014). Physicochemical profile and sensory evaluation of cakes with flaxseed and yacon flour associated to sweeteners. Boletim Do Centro de Pesquisa de Processamento de Alimentos, 32 (1). doi: https://doi.org/10.5380/cep.v32i1.36988

[8] Agarwal, V., Kochhar, A., Sachdeva, R. (2009). Sensory and Nutritional Evaluation of Sweet Cereal Products Prepared Using Stevia Powder for Diabetics. Studies on Ethno-Medicine, 3 (2), 93-98. doi: https://doi.org/10.1080/09735070.2009.11886344

[9] Moraes, É. A., Dantas, M. I. de S., Morais, D. de C., Silva, C. O. da, Castro, F. A. F. de, Martino, H. S. D., Ribeiro, S. M. R. (2010). Sensory evaluation and nutritional value of cakes prepared with whole flaxseed flour. Ciência e Tecnologia de Alimentos, 30 (4), 974-979. doi: https://oi.org/10.1590/s010120612010000400021

[10] Alpaslan, M., Hayta, M. (2006). The effects of flaxseed, soy and corn flours on the textural and sensory properties of a bakery product. Journal of Food Quality, 29 (6), 617-627. doi: https://doi.org/10.1111/ j.1745-4557.2006.00099.x 